\section{Сенка Анастасова}

Чиста Дана: кон

Јасна Котеска,

\section{Санитарна енигма,}

Темплум, Скопје, 2006.

\section{Senka Anastasova}

Danës së pastër: për

Јасна Котеска,

\section{Санитарна енигма,}

Темплум, Скопје, 2006.
Во првата деценија од овој век, на македонската книжевна сцена се јавуваат неколку авторски имиња кои со својот теориски дискурс и истражувачки теми на интерес го „минираат“ досегашниот тек и поредокот на метатекстуалноста, сфатена во широк спектар на нашиот јавен културен контекст. Една од тие авторки е Јасна Котеска, чијашто истражувачка работа се фокусира врз повеќе дисциплини како што се женското писмо, теориската психоанализа, книжевната теорија, родовите студии. Санийарна енигма(2006)воизданиенаТемплум,енејзинататрета теориска книга. Оваа студија претставува сериозно суштествено размислување за маргинализираниот феномен на чисииойо и нечисииойо, внимателно исчитано низ психоаналитичката теорија на Фројд (Freud) и Јулија Кр(и)стева (Julija Kristeva). Во оваа книга, при преиспитувањето на културното и субјективно себеискуство, Јасна Котеска (речиси постојано неочекувано) „фрла“ в лице кутии со моќни тези, контратези, аргументи, асоцијации и прецизни поентирања, кои на неколкупати во текот на истражувањето го пренасочуваат текот на анализата во создавање лична физиономија на авторката. Да се даде (одново) простор на Фројд во овие години на овој век, значи да се преземе ризикот
Në decenien e parë të këtij shekulli, në skenën letrare maqedonase paraqiten disa emra autorialë të cilët me diskursin e tyre teorik dhe me temat hulumtuese e "minojnë" ecurinë e deritashme si dhe rendin e metatekstualitetit, të kuptuar bë një spektër të gjerë të kontekstit tonë publik kulturor. Njëra nga këto autore është Jasna Koteska puna hulumtuese e së cilës fokusohet në shumë disiplina siç janë shkrimet e femrave, psikanaliza teorike, teoria letrare, studimet gjinore. Enigma sanitare (2006) është libri i saj teorik në botim të Templum-it, ky studim paraqet një përsiatje serioze për fenomenin e margjinalizuar të së pastrës dhe të së papastrës, të lexuar me kujdes nëpër teorinë e psikanalitike të Frojd-it dhe Julija Kristevës. Në këtë libër Jasna Koteska, me rastin e rishqyrtimit të përvojës kulturore dhe subjektive (thuajse vazhdimisht papritur) "hedh" në fytyrë kutitë me teza të forta, kontrateza, argumente, asociacione dhe poentime të përpikta të cilat disa herë rreth gjatë hulumtimit, e kthejnë rrjedhën e analizës - në krijimin e fizionomisë personale të kësaj autoreje. T’i jepet (përsëri) hapësirë Frojdit në këto vite të këtij shekulli, domethënë të merret përsipër rreziku që librin ta përfundojë si homazh për tezat që Frojdi i shtroi bindshëm. Por, Jasna Koteska e pranon ringun që t’i nxjerrë "prej dheu" kategorizimit tashmë të etabluara 
книгата да заврши како омаж за тезите што Фројд уверено ги поставил. Но, Јасна Котеска застанува во рингот и го прифаќа предизвикот да ги „раскопа“ веќе етаблираните категоризации од доменот на психоанализата и, во широк опсег, да ја поттурне санитарноста - од „срамното“, ниско културно ниво - кон еден поширок општествен и културолошки феномен на интерпретација, а со тоа повторно да укаже на генеричката семантика за почетоците на субјективноста. Јасна Котеска со оваа книга успешно ја ревидира теоријата за санитаризацијата, притоа кодификувајќи една „своја“, „сопствена“ терминологија, која во исто времестанува препознатлива иубедливазапошироколегитимнитеепистемолошки прототипи во македонската наука за книжевноста. Ваквата интонација на оваа научна студија отвора нова врата за компетентно, сериозно, учено и, во исто време, „вертикално“ читање на академските книги, со висок праг на толеранција за „високата“ наука и секојдневното искуство.

Поттикот да пишувам за Санийарна енигма произлегува од тоа што оваа книга се наметнува непретенциозно со нејзиниот лагоден тек на читливоста, обидувајќи се, во извесна смисла, преку проблемот на санитарноста, да го разобличи пасивното потрошувачко општество, за коешто сме сведоци дека, во оваа доба, „весело“ (си) паратизира за сметка на туѓото страдање. Овој момент ќе ми биде интерпретативно значаен во овој есеј. Притоа, овде, нема да ми биде целта да ги коментирам психоаналитичките методи (сами по себе) во однос на санитарноста, ниту почетоците и основите на субјективноста, туку во нивната заднина/периферија ќе се обидам да ги пронајдам и интерпретирам врските на санитарноста со менаџирањето на потрошувачките интереси, технологијата на nga domeni i psikanalizës dhe, në një hapësirë të gjerë, ta shtyjë tutje sanitarësinë - nga e "turpshmja", nivel i ulët kulturor - kah një fenomen më i gjerë shoqëror e kulturologjik i interpretimit, e me këtë, sërish të bëjë me dije semantikën gjenerike për fillimet e subjektivitetit. Jasna Kotevska me këtë libër me sukses e revidon teorinë e sanitarësisë, duke kodifikuar me këtë rast një terminologji “të veten”, "vetanake”, e cila njëherësh bëhet e njohur dhe e bindshme për prototipet me legjitimitet më të gjerë epistemologjik në shkencën maqedonase të letërsisë. Intonimi i tillë i këtij studimi shkencor i hap dyert për një lexim kompetent, serioz, të dijshëm dhe njëherësh edhe "vertikal" të librave akademikë, me një prag të lartë të tolerancës për shkencën "e lartë" dhe përvojën e përditshme.

Të shkruajë për këtë libër më shtyri fakti se ai imponohet me lehtësinë e leximit, duke u orvatur, në njëfarë mase, përmes problemit të sanitarësisë, ta demaskojë shoqërinë pasive konsumuese, për të cilën jemi dëshmitarë se "po paraziton" në kurriz të fatkeqësisë së huaj. Ky moment do të jetë i rëndësishëm në kuptimin interpretues në këtë ese. Me këtë rast, në këtë ese, nuk do ta kem për qëllim t'i komentoj metodat psikanalitike në raport me sanitarësinë, as fillimet dhe themelet e subjektivitetit, por, në prapavijën/periferinë e tyre, do të orvatem $t[i$ gjej dhe $t[i$ interpretoj lidhjet e sanitarësisë me menaxhimin e interesave konsumuese, teknologjinë e shikimit në kulturën vizuale dhe histerinë e kulturës konsumuese sot, që janë të vëna në dukje në disa vende në këtë libër. 
гледањето во визуелната култура и хистеријата на потрошувачката култура денес, исчитани на неколку места во оваа книга.

\section{1. „Валкани” теориски процепи: Дамски илузии}

Валканицата е во телото на текстот и во телото на мислата. Уште повеќе, самата теорија е процеп, валканица во поредокот, во светот, во системот на живеењето. Нашата културна продукција во извесна смисла не е ништо друго освен загадување, а референцирањето е бескрајна депонија на мислата, своевидно ѓубриште. (Котеска 2006), 227.

Книгата Санийарна енигма е поделена во три блока: 1. Санитарна енигма; 2. Санитарна ера и 3. Проширен субјект. На прв план, ова е студија за напнатоста помеѓ културата и субјектот, експлицитно образложена од Фројд во „Неугодното во културата“. Кај Фројд, феноменот за санитарноста останува по рабовите на неговото истражување. Јасно е дека тој го врзува чистото за потребата од убавина и ред. Редот кај него стои во врска со небесната хармонија, важна поради психичката економија, бидејќи за Фројд не постои метафизичка оправданост за ваквата хармоничност. Јасна Котеска со право заклучува уште во воведниот дел од истражувањето дека феноменот на санитарноста не може да биде решен од првата генерација пост Постфројдовци, затоа што и самата покажувала зазор кон дупките, валканиците и дилемите во самата фројдовска доктрина. Сета работна енергија таа генерација ја насочила кон тоа, како што вели Лакан - „да ги заsида 'процепите' во неговата сопствена теорија“ (26). Оттука, Јасна Котеска ја отвора фамозната теорија на „процепот“ и натаму, во текот на истражувањето, се повикува на школата на Жак Лакан (Jacques Lacan). Факт е дека оваа школа,

\section{Plasa "të ndyra" Teorike: Iluzione damash}

Ndyrësia është në trupin e tekstit dhe në trupin e mendimit. Aq më shumë, vetë teoria është një plasë, ndyrësi në rend, në botë, në sistemin e jetesës. Produksioni ynë kulturor në njëfarë kuptimi nuk është asgjë tjetër përveç se ndotje, ndërsa referencimi është një deponi e pafund e mendimit,

plehnajë e farës së vet.

(Котеска 2006), 227

Libri Enigma sanitare ështëndarënëtriblloqe: 1. Enigma sanitareë 2. Era sanitare dhe 3. Subjekti i zgjeruar. Në plan të parë, ky studim për tendosjen midis kulturës dhe subjektit, është shpjeguar në mënyrë eksplicite nga Frojdi në veprën "Papërshtatshmëria në kulturë". Te Frojdi fenomeni i sanitarësisë mbetet skajeve të hulumtimit të tij. Është e qartë se ai e lidh të pastrën me nevojën për bukuri dhe rend. Rendi te ai qëndron në lidhje me harmoninë qiellore, të rëndësishme për shkak të ekonomisë psikike, nga se për Frojdin nuk ekziston arsyeshmëria metafizike për nj[ harmoni të këtillë. Jasna Koteska me të drejtë vjen në përfundim që në pjesën hyrëse të të hulumtimit, se fenomeni i sanitarësisë nuk mund të zgjidhet nga brezi i parë pasfrojdianë për shkak se ajo edhe vetë tregon njëfarë mosdurimi ndaj birave, ndyrësive dhe dilemave në vetë doktrinën e Frojdit. Tërë energjinë punuese ky brez e ka orientuar kah fakti, siç thotë Lakani - "t'i murojë 'plasat' në teorinë e tij” (26). Së këndejmi, Jasna Koteska e hap teorinë famoze "të plasës" dhe më tutje gjatë hulumtimit, thirret në shkollën e Zhak Lakanit. Është fakt se kjo shkollë, megjithatë, në rrugë e sipër e "përfshin" fenomenin e enigmës sanitare (më shumë e shpjegon si të panjohur diktat të super 
сепак, попатно го „зафаќа“ феноменот на санитарната енигма (повеќе ја толкува како диктат на суперегото), ама, од друга страна пак, не ја цензурира дилемата за опскурноста на редот и хигиената. Тука е придобивката на оваа школа. Протолкувано во лакановски дух, Јасна Котеска нечистото гоанализира како „есхатолошка дупка која голта сѐ од супстанцата на светот, освен еден вишок кој таа ништожност не може да ја проголта - а тоа е желбата“ (27). Лакан функционира според $u$ - $и$ можноста/изборот (не $и л и-$ uли). За него чистото е она кое овозможува удобност, лежерност во амбивалентниот поредок. Котеска констатира: „ти нему му помагаш тој да се претстави како едно/моно/валентен поредок, но за возврат, тој, поредокот, тебе ти го дозволува чувството дека со тебе ‘cè е во ред'!” (28).

Очекувано е што на лакановската методологија околу феноменот на санитарноста, Ј. Котеска ги надоврзува анализите на Славој Жижек, особено пасажите за

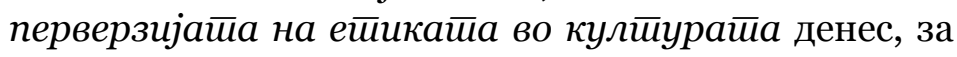
неможноста од тоа да се спроведе отпор од страна на потчинетиот, неможноста да се прикријат докрај трагите на „злосторството“, неможноста докрај да се исцеди и да се фрли фекалијата, која не се вклопува во нашата секојдневица и поредок, и без да се сака, постојано излегува на виделина при тој процес на „тоалетирање“ на културата.

На опачината од теориската психоаналитичка методологија на Фројд, Лакан, Жижек - Јасна Котеска во оваа студија прави сериозен хронолошки осврт на феноменот за санитарното, осцилирајќи околу работата на Мелани Клајн (Melani Klein), Мери Даглас (Mary Douglas) и Јулија Кр(и)стева. Кр(и)стева и нејзината книга „Моќта на ужасот: есеј за абјектот“ (1980) е епохален пресврт во психоаналитичките тол- egos), por nga ana tjetër, nuk e censuron dilemën për obskurësinë e rendit dhe të higjienës. Këtu qëndron frytnia e kësaj shkolle. Duke e shpjeguar në frymën e Lakanit, të papastrën Jasna Koteska e analizon si "birë eshatologjike e cila përbin gjithçka nga substanca e botës, përveç një teprice të cilën ajo pavlerësi nuk mund ta gëlltisë - kurse kjo është dëshira" (27). Lakani funksionon sipas e-e mundësisë/zgjedhjes (jo ose-ose). Për të e pastra është ajo që mundëson rehati, leyheritet në rendin ambivalent. Koteska konstaton: "Ti atij i ndihmon që ai të prezantohet si rend një/mono/talent, ndërsa si përgjigje, ai, rendi, ty ta lejon ndjenjën se me ty 'gjithçka' është në rregull”' (28).

Pritej që në metodologjinë e Lakanit rreth fenomenit të sanitarësisë Koteska i ndërlidh analizat e Slavoj Zhizhekut, veçanërisht pasazhet për perversitetin e etikës në kulturë sot, për pamundësinë që nga ajo të zbatohet një rezistencë nga ana e të nënshtruarit, pamundësia që të fshihen deri në fund gjurmët e "krimit", pamundësia që deri në fund të shtrydhet dhe të hidhet fekalja, e cila nuk gjen vend në përditshmërinë dhe në rendin tonë edhe pa dashur, vazhdimisht del në syprinë, gjatë atij procesi të “tualetizimit” të kulturës.

Në prapavijë të metodologiisë teorike psikanalitike të Frojdit, Lakanit, Zhizhekut - Jasna Koteska në këtë studim e bën një shqyrtim serioz kronologjik tëfenomenit për sanitaren, duke osciluar rreth punës së Melani Klajnit (Melani Klein, Meri Daglasit (Mary Dovglas) dhe Julia Kristevës dhe librit të saj "Fuqia e tmerrit: ese për abjektin" (1980) është një kthesë epokale në shpjegimet psianalitike të identitetit. Koteska e do Kristevën, më 
кувања на идентитетот. Котеска ја сака Кр(и)стева, најмногу поради теоријата за абјектноста. Абјекӣой (презрено, подло, ниско, зазорно) е феномен со богато семантичко ниво на интерпретација, а овој поим во оваа книга се врзува за санитарноста и се развива во сериозен сооднос со моралой, со идеолошкиие

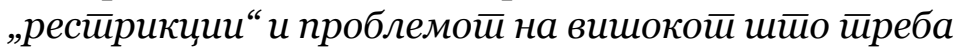
да се понишиши. Со внимателност се образложува

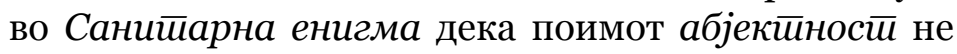
укажува на физичката нечистотија, туку повеќе на моралното, социолошкото и културно згрозување и паѓање. Санишарна енигма може слободно во

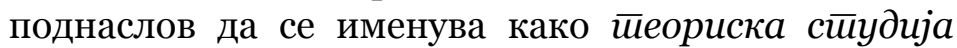

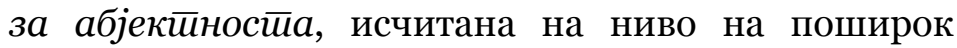
општествен и културен контекст. Теоријата за абјектноста во оваа книга стои во ко-партнерство со Лакан, од кајшто Котеска го извлекува проблемот на симболичкойо. Токму во овој феномен на симболичкото се содржи дамайа (пациентката) на Балинт:

„Основниот парадокс на симболниот поредок е 'дамското, всушност детско, инфалтилно одбивање да се биде врзан со договор. Поентата на договорот во симболиот поредок е субјекот да биде врзан со контрадикцијата, со амбивалентноста која секогаш се содржи во говорот како таков“ (53).

„Дамскиот“ парадокс за којшто зборува Котеска е парадокс што е кодиран во културниот поредок и тешко дека може да се излечи. Имено, тоа е проблемот на симболичкото кое одново се чита преку промашувањето на ознаката со означеното, а субјектот се конфронтира со амбивалентноста на јазикот. Тоа е приказната дека јазикот (колку и да сака) не ја кажува вистината. së shumti për shkak të teorisë si objektivitetit. Abjekti (në mënyrë të urryer, të ulët, të poshtër, të ndyrë) është fenomen menjënivel tëpasur semantiktëtëinterpretimit, kurse ky kuptim në këtë libër lidhet me sanitarësinë dhe zhvillohet në një bashkëqëndrim serioz me moralin, me "restrikcionet" ideologjike dhe me problemin e tepricës $q \ddot{e}$ duhet të zhduket. Me kujdes arsyetohet në Enigmën sanitare se kuptimi objektivitet nuk e vë në dukje papastërtinë fizike, por më shumë rënien dhe gërdinë morale, sociologjike dhe kulturore. Enigma sanitare mundet lirisht në nëntitull të quhet si studim teorik për objektivitetin, e lexuar në nivelin e një konteksti më të gjerë shoqëror e kulturor. Teoria për abjketivitetin në këtë libër qëndron në bashkpartneritet me Lakanin, prej nga Koteska e nxjerr problemi e simbolikes. Pikërisht në këtë fenomen të simbolikes përfshihet dama (pacientja) e Balintit:

"Paradoksi themelor i rendit të simboltë është 'damorja', në të vërtetë refuzimi fëmijëror, infantil, të jesh i lidhur me marrëveshjen. Poenta e marrëveshjes në rendit e simboltë është subjekti të jetë i lidhur me kontradikcionin, me ambivalentninë e cila gjithmonë gjendet në të folur si i tillë” (53).

"Paradoksi "damor" për të cilin flet Koteska është paradoks që është koduar në rendin kulturor dhe vështirë se mund të shërohet. Pra, ky është problemi i simbolikes e cila sërish lexohet përmes shmangies së gabueshme të shenjës me të shënuarën, kurse subjekti konfrontohet me ambivalentninë e gjuhës. Ky është rrëfimi se gjuha (sa do që të dojë) nuk e tregon të vërtetën. 


\section{2. Первертирање на вишокот вредност}

Јасна Котеска во Санийарна енигма ги разобличува морничавите ефекти на потрошувачката индустрија денес - и тоа сведена во исклучителните мали метафори на сапуной, како еуфемизам за витките/ салото, свинското и човечкото месо - месарски или прецизно откорнато, во име на „повозвишени“ цели." Како теоретичар(к)и на современото време, се соочуваме со поразителниот факт дека сапунот кој чисти е произведен од нечист вишок. Сапунот, од свинско потекло, во цела палета на сопствената бизарност, е средство за чистење, и истовремено производ произведен од нечистото, од несаканите „парцели“ на богатите задници во светот кои, по хистеричните липосукциски зафати, повторно си ги купуваат своите телесни исцедоци за чистење. (Совест?)

Дали ваквите „чисти“ задници добро се обезбедуваат себеси со йампони - одново како метафори/ штитови за отпор против валканицата? Такви се влошките за менструалната крв, тампоните за затнување на дупките од одводните и каналните

* Јасна Котеска во главата „Сапун и фашизам“ го коментира плакатот за култниот „Боречки клуб“ (Fight Club, 1999), филм на Дејвид Финчер, на којшто Бред Пит, кој го игра Тајлер Дарден, држи сапун на којшто е испишана пораката „Боречки клуб“. , „Сапун: мерило за цивилизацијата. Правам и продавам сапуни“ - вели Тајлер Дарден. Котеска го поставува прашањето каков е боречкиот клуб произлезен од сапунот и каква е врската помеѓу чистотата и борбата?... Имено, нараторот, кој го среќава своето алтер-его Тајлер Дарден во авион, работи во фирма која профитира од парите изгубени во судски тужби за сообраќајки, значи својот свет го гради од потенцијалните безимени трупови кои носат профит.. Нараторот порано читал порнографија, сега логично чита потрошувачки каталози за мебел од Икеа...(124-125).

\section{Pervertimi i tepricës së vlerës}

Jasna Koteska në Enigmën sanitare i demaskon efektet e ethshme të industrisë konsumuese sot - të reduktuar në metafora krejtësisht të vogla të sapunit, si eufemizëm për të hollët e të gjatët/dhjamit, mishit të derrit e të njeriut - të këputur si kasap ose me përpikëri, në emër të qëllimeve "më të larta"*. Si teoricienë(e) të kohës moderne ballafaqohemi me faktin dëshpërues se sapuni i cili pastron prodhohet nga teprica e papastër. Sapuni, me origjinë derri, në tërë paletën e bizaritetit të tij, është mjet pastrimi dhe njëherësh një gjë e prodhuar nga papastërtia, nga "parcelat" e padëshiruara të prapanicave të pasura në botë, të cilat, pas ndërmarrjeve liposuksionalisht histerike, sërish i blejnë shtrydhma e tyre trupore për pastrim. (Ndërgjegje?)

A e sigurojnë mirë vetveten këto prapanica "të pastra" me tamponë-sërish si metafora/mburoja për rezistencë kundër ndyrësisë? Të tilla janë leckat për gjakun menstrual, tamponat për yënien e birave të gypave të kanaleve të gjirizit nëpër shtëpi, të cilat shpijnë në të

* Јacна Koteska në kapitullin "Sapuni e fashizmi” e komenton pllakatin për filmin kult "Klubi i mundësve" (Fight Club, 1949), film i Dejvid Finçerit, në të cilin Bred Piti e luan Tajler Dardenin dhe e mban një sapun në të cilin është shkruar mesazhi "Klubi i mundësve". "Sapuni": masë për civilizimin. Bëj dhe shes sapuna" - thotë Tajler Dardeni. Koteska e shtron pyetjen se çfarë është klubi mundësve i dalë nga sapuni dhe cila është lidhja midis pastërtisë dhe luftës?... Pra naratori, i cili e takon alter egon e tij - Tajler Dardenin në avion, punon në një firmë e cila profiton nga paratë e humbura në paditë gjyqësore për komunikacion, domethënë botën e vet e ndërton nga biznesmenët potencialë, trupa që sjellin profit... Narratori ka lexuar me porosi pornografi, tash, është logjike, lexon katalogë konsumues për mobilje nga Ikea... (124-125) 
цевки во домаќинството кои водат во есхатолошката непознатица во оностраниот свет. Сапунот и тампо-

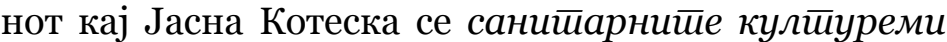
интерпретирани како чистачи и затнувачи на негатитивот на горното, на постоењето на онаа паралелна онтологија на подземниот свет, која постои како депонија за сите телесни вишоци и зазорности од овој свет.

Ваквото теориско преиспитување на санитаризацијата од Јасна Котеска, контекстуалнојапревреднува и онаа куса песна „Чиста Дана“ што ја учат напамет децата во Македонија, од којашто произлегува слоганот „чистотата е половина здравје“. Песната оди вака: „На утрина штом си стана/на бунарот брза Дана/вади вода и се мие/лице, уши, таа трие/ Нечистотија не трпи/еве, втора кофа црпи/Знае Дана мома мила/чистотата дава сила“. Ако канонот е победа над загадувачката теорија, тогаш се отвора позиција за (скандалозно!) преиспитување на слоганот чистото е половина здравје - добро воиграна и канонизирана синтагма и упорно наметнувана од цела цивилизација и култура. Во делот „Табуизирани отпосле: онтологијата на абјектот“, Котеска студиозно ја изнесува онтологијата на абјектот, укажувајќи дека „на културата ѝ е потребно да ги скрие абјектните/ зазорни феномени. Културата го гони, го крие, го истиснува опскурното зазорно, вишокот, затоа што се плаши од неговата моќ врз субјектот“ (97). Таков е примерот со повраќаницата:

Повраќаницата која била дел од субјектот, во моментот кога се објективизира, повеќе од сите други објекти, таа станува опасна и за мене како конституиран субјект. Абјектот/зазорот стои помеѓу субјектот и објектот. Еднаш дел од субјектот, повраќаницата станува нешто налик на објект, но ниеден човек не може да му снабди исцело статус на објект, токму бидејќи меморијата за потеклото е сѐ уште свежа (98). panjohurën eshatologjike në botën e përtejme. Sapuni e tamponi te Jasna Koteska janë kulturoma sanitare të interpretuara si pastrues dhe zanca të negativit në të sipërmen, më ekzistimin e asaj ontologjie paralele të botës së nëntokës e cila ekziston si deponi për të gjitha tepricat trupore dhe neveritë e kësaj bote.

Shqyrtimi i tillë teorik i sanitarësisë nga Jasna Koteska, kontekstualisht e rivlerëson edhe atë vjershën e shkurtër "Dana e pastër" të cilën e mësojnë përmendësh fëmijët në Maqedoni, prej të cilës del slogani "pastërtia është gjysma e shëndetit". Vjersha shkon kështu: "Në mëngjes sa u ngrit/ dhe kovën e dytë e nxjerr/ e di Dana vajzë e mirë/ pastërtia jep fuqi”. Nëse kanuni është fitore mbi teorinë ndotëse, atëherë hapet pozicioni për rishqyrtimin (skandaloze!)tësloganitpastërtiaështëgjysmaeshëndetit - një sintagmë e futur mirë në lojë dhe e kanonizuar dhe e imponuar nga mbarë civilizimi dhe kultura. Në pjesën "Të tabuizuar pastaj: ontologjia e objektit" Koteska në mënyrë studioze e shtron ontologjinë e objektit, duke bërë me dije se "kultura ka nevojë t'i fshehë objektet/ fenomene të neveritshme. Kultura e ndjek, e fsheh, e shtrydh të neveritshmen obskure, tepricën, për shkak se ka frikë nga fuqia e saj mbi subjektin” (97). I tillë është rasti me të vjellit:

E vjella e cila ka qenë pjesë e subjektit, në momentin kur objektivizohet, më shumë se objektet tjera, ajo bëhet e rrezikshme edhe për mua si subjekti i konstituar. Objekti/neveria qëndron midis subjektit e objektit. Një herë një pjesë e subjektit, e vjella bëhet diçka e ngjashme me objektin, por asnjë njeri nuk mund t'i sigurojë plotësisht status objektit, pikërisht për shkak se memoria për zanafillën është ende e freskët (98). 
Постои културолошки напор (стомакот на современиот човек е крајно „чувствителен“) за санкционирање/социјализирање на ваквите абјектни материјали, како: плунка, менструална крв, измет, повраќаница, мочка, пот, фекалии. Културата ги санкционирала/табуизирала нив како закана за стабилноста на субјектот (болести, нечистотија) како НЕЧИСТО, а на тој начин и како огрешување од поредокот, кое Котеска го поврзува со репродукци-

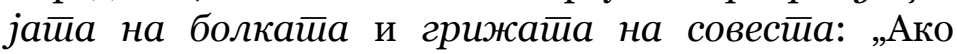
сакаш да продолжиш да се пазариш, ако сакаш да продолжиш да бидеш во системот (затоа што тоа е единствениот услов да бидеш), тогаш мора да чистиш. Со чистењето на системот му гарантираш дека ќе бидеш фиксен, дека ќе чистиш од тебе сѐ што е вишок“ (99). Котеска не го исклучува извесното валкано и на самата теорија, на текстот, „нечисто“ во мислата, па дури $u$ во теоријата на Кр(и)стева за валканото, оној вишок смисла, вели Котеска, кој ја прави целата теорија за абјектот покомплексна (227).

На една ваква психоаналитичка спрега од интерпретативни методи во Санийарна енигма, се создава можност да се произведат нови потенцијални научни метадискурси во македонската истражувачка и научна јавност. Имено, актуализирајќи ја моќната слика на прикривање на стварноста, Јасна Котеска покажува дека работат цели креативни индустрии во коишто се вложени милионски суми за ЦЕНЗУРА НА ВАЛКАНИЦАТА. Тоа особено доаѓа до израз во услови на капиталистичките пазарни вредности, каде што се форсираат глобалните потрошувашки вкусови и корпорациските интереси кои го интензивираат чувството на потреба и зависност кај потрошувачите. Постои цела една игра на криенка на валканото во постиндустриското, информатичко
Ekziston një mund kulturologjik (lukthi i njeriut bashkëkohor është skajshëm i "ndjeshëm") për sanksionimin/socializmin e materialeve të tilla abjekte si: pështyma, gjaku menstrual, e pëgëra, e vjella, shurra, djersa, fekalet. Kultura i ka sanksionuar/tabuizuar ato si kanosje për stabilitetin e subjektit (sëmundje, papastërti) - si E PAPASTËR, e kësisoj edhe si bërje gabim ndaj rendit, të cilin Koteska e lidh me reproduksionin $e$ dhembjes dhe brejtjen e ndërgjegjes: "Nëse dëshiron të vazhdosh të bësh pazar, nëse vazhdon të jesh në sistemin (për shkak se ky është kushti i vetëm të jesh), atëherë je detyruar të pastrosh. Me pastrim sistemit i garanton se do të jesh fiks, se do të pastrosh nga vetja çdo gjë që është tepricë" (99). Koteska nuk e përjashton njëfarë ndyrësie edhe të vetë teorisë, të tekstit, "të papastrën" në mendim, madje edhe në teorinë e Kristevës për të ndyrën, atë tepricë kuptimi - thotë Koteska i cili e bën tërë teorinë për objektin më kompleks (227).

Në një ndërlidhje të këtillë psikanalitike nga metodat interpretuese në Enigmën sanitare, krijohet mundësia të prodhohen metadiskurse shkencore potenciale të reja në publikun maqedonas hulumtues e shkencor. Pra, duke e aktualizuar imazhin e fuqishëm të fshehjes së realitetit, Jasna Koteska tregon se punojnë industri të tëra kreative në të cilat janë shpenzuar shuma milionëshe për CENSURËN E NDYRËSISË. Veçanërisht kjo vjen në shprehje në kushte të vlerave kapitaliste të tregut, ku u jepet forcë shijeve globale konsumuese dhe interesave të korporatave të cilat e intensifikojnë ndjenjën e nevojës dhe të varshmërisë te konsumatorët.. Ekziston një lojë e tërë symbyllas e ndyrësisë në shoqërinë postindustriale, informatike. Jemi dëshmitarëtë manipulimit meimazhe/ pasqyrimet/konstruktet imagologjike për konsum masiv, 
општество. Сведоци сме на манипулација со сликите/претставите/имаголошките конструкти за масовна потрошувачка, чијашто цена ја плаќа самиот потрошувач. Во едно свое интервју Котеска вели:

Тоа го спроведуваат носителите на културата. Ги препознаваме во медиумските могули, во мултинационалните компании, во сите кои имаат корист да ве вбројат како потрошувач. Тие го користат нечистото како иконографски режим за продукција на страв. Медиумите рано сфатија дека кој го владее чистото, тој е господар на светот. Кога Си-Ен-Ен ќе пласира режим на избрани медиумски слики, вие знаете дека тој го диригира вашето поведение (Теа Модерна, 2007).

Новата произведувачка медиумска динамика драматично воведува фрагмениирање на чисӣоӣо. Ваквото фрагментирање на чистото кај Јасна Котеска треба да се сфати како нејзина блискост со Жил Делез, кога во „Анти Едип“ зборува за „телото без органи“. Ваквото тело без органи е културна консеквенца на капиталистичката мисла. Имено, телото без органи е оној расклопен организам кој предизвикува чист интензитет, кој поминува, циркулира и себеси си придодава субјекти кои понатаму живеат без ништо друго, освен со име, кое е трага од интензитетот $(1996,4)$. Натаму, произлегува постоење на една цела фабрика од еуфемизми кои го „разубавуваат“ капиталистичкото нечисто, кои компензираат во

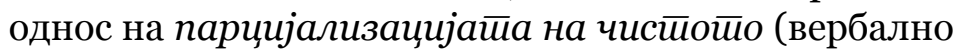
или визуелно искажано во културниот контекст). Ваквиот имиџ на „кастрирана“ чистост има свој аналогон во шизоаналичкиот капиталистички де-територијализиран субјект (Делез). Практиките на мимикријата на зазорите, се секојдневни: Смртта вешто се крие зад секојдневното вклучување и исклучување на копчето на нашиот компјутер, зад виртуелните текстови на нашите монитори; Документите, тек- çmimin e të cilave e paguan vetë konsumatori. Në një intervistë J. Koteska thotë:

Këtë e zbatojnë bartësit e kulturës. I njohim në mogilat mediave, në kompanitë multinacionale, te të gjithë që kanë dobi t’ju fusin në numrin e konsumatorëve. Ata e shfrytëzojnë të papastrën si regjim ikonografik për produksionin e frikës. Mediat e kuptuan herët se kush e sundon të pastrën, ai është zotërues i botës. Kur CNN do të plasojë një regjim të imazheve të zgjedhura mediave, ju e dini se ai e dirigjon sjelljen tuaj (Теа Модерна, 2007).

Dinamika e re prodhuese mediatike nëmënyrë dramatike e fut fragmentimin e të pastrës. Fragmentimi i tillë i të pastrës te Jasna Koteska duhet të kuptohet si afëri e saj me Zhyl Delezin kur në "Anti Edip" flet për "trupin pa organe". Trupi i këtillë pa organe është konsekuencë kulturore e mendimit kapitalist. Pra, trupi pa organe është një organizëm i çmontuar i cili e nxit intensitetin e pastër, i cili kapërcen, qarkullon dhe i shton vetes subjekte të cilat më tej jetojnë pa asgjë tjetër, përveç se me emër, përveç se me emrin, i cili është gjurmë e intensitetit (1996, 4). Më tutje, del ekzistimi i një fabrike të tërë eufemizmash të cilët e "zbukurojnë" të papastrën kapitaliste, të cilët kompensojnë në raport me parcializimin e të pastrës (thënë verbalisht ose vizualisht në kontekstin kulturor). Vizioni i këtillë i pastërtisë së "tredhur" e ka analogonin e saj në subjektin shizoanalitik kapitalist të deterritorializuar (Delez). Praktikat e mimikrisë së neverive janë të përditshme: Vdekja diçka fshihet prapa shtypjes dhe të mbylljes së përditshme të sustës së kompjuterit tonë, prapa teksteve virtuale të monitorëve tanë; Dokumentet, tekstet që i shkruajmë, fotografitë që i hedhim nga aparati ynë digjital në kompjuter - janë grumbuj materialesh virtuale të cilat i mbajmë në mend 
стовите кои ги пишуваме, фотографиите кои ги префрлуваме од нашиот дигитален апарат во компјутер - се купишта виртуелни материјали кои ги запомнуваме во „празните“ фолдери кои не можеме стварно да ги допреме, а со сигурност сметаме на нив („ги имаме“ за свои); Високата модна индустрија со брзина на торнадо ги покрива телата на анорексичните/булимични девојки со скапоцени дизајнерски фустани, а по завршувањето на модните ревии, модните критичари едноставно јавно ги коментираат очекувањата - дали ревијата била успешна или не; Парадоксалноста на интернетмрежите и спроведувањето на имагинарната санитарна цензура во однос на трупањето виртуелно ѓубре и спамовите во електронските сандачиња; Жолтиот печат кој секојдневно ги следи аферите на поп-sвездите, а ги раслабнува скандалите пакувајќи ги во евтини клип/видео изданија, достапни за гледање и умножување како прототипи за еден приватен свет, а всушност дебел корпорациски капитал од којшто живеат цели светски публицистички агенции; А, телевизиите? Многуте програми кои се следат

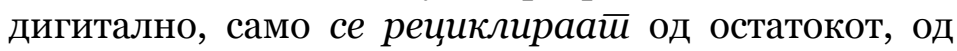
потрошливиот материјал во име на комерцијалните цели; Постои цела една маскарада и деконструкција на женското тело во музичките спотови на македонската сцена. Екипирани се погледите на гледачите во име на продолжување на стереотипите на женственоста. Се ужива во гледањето. Жените се третирани низ драматична порноглосија, од еден мачистички аукторијален поглед, од мизогинистичка (женомрзечка) перцепција, а како што вели Андреас Хајсен (Andreas Huyssen) (1986), односот помеѓу произведувањето и потрошувачката во капиталистичката економија е секогаш родово обоен; Од друга страна, целиот процес на продукција денес станува сѐ поотежнато видлив за гледачот. Во прехранбената индустрија, храната се крие во në folderët "e zbrazët” të cilët nuk mundemi t’i prekim në realitet, e me siguri i mbajmë shpresat te ata ("i kemi" për tanët), Industria e lartë e modës me shpejtësinë e tornados i mbulon trupat e vajzave anoreksike/bulimike me fustane të shtrenjta desenerikë, e pas mbarimit të revyve të modës, kritikët e modës thjeshtë i komentojnë publikisht pritjet - a ka qenë revyja e suksesshme ose jo; Paradoksaliteti i internet rrjetave dhe zbatimi i censurës imagjinare sanitare në raport me grumbullimin e plehut virtual dhe të dhe spamet në arkat elektronike; Shtypi i verdhë i cili për çdo ditë i ndjek aferat e pop yjeve, e i zbut skandalet duke i paketuar në klip/video edicione të lira, me qasje të lehtë për t'i shikuar dhe për t'i shumëzuar, si prototipe për një botë private, ndërkaq në thelb një kapital i rrastë korporativ nga i cili jetojnë agjenci të tëra botuese botërore; Po Televizionet? Shumë programe që ndiqen në mënyrë digjitale, vetëm riciklohen nga mbetja e materialit konsumues në emër të qëllimeve komerciale; Ekziston një maskaradë dhe një dekonstruksion i tërë i trupit të femrës në spotet muzikore të skenës maqedonase. Janë ekipuar pikëpamjet e shikuesve në emër të vazhdimit të të stereotipeve të feminitetit. Kënaqen duke shikuar njerëzia. Gratë trajtohen nëpër pornoglosinë dramatikew, me një pikëpamje autoriale maçistike, nga percepcioni mizoginistik, e si thotë Andreas Hajseni (Andreas Huyssen) (1986) raporti midis prodhimit dhe konsumit në ekonominë kapitaliste është gjithmonë i ngjyrosur me gjini; Nga ana tjetër, i tërë procesi i produksionit sot bëhet gjithnjë e më vështirë i pashëm për shikuesin. Në industrinë ushqimore, ushqimi fshihet në njëfarë disejni të mbështjellë për përdorim vetëm për një herë. Emisionet kulinare për së gjalli ( të replikuara obsesisvisht dhe masivisht nganë të gjitha TV kanalet maqedonase) janë "kontakti" më i moçëm me realitetin dhe "gjallërinë" - për ata që janë të papunësuar dhe rrinë në shtëpi, të cilët për "ngushëllim” barazohen me shfaqjet e mediave. Serialet e lira bëhen këmbim thelbësor i mendimeve. Dhe komunikim "i 
вешто спакуван дизајн за еднократна употреба. Кулинарските емисии во живо (опсесивно и масовно реплицирани на сите македонски ТВ канали) - се „најстварниот“ допир со стварноста и „живоста“ - за оние кои се невработени и седат дома, кои „утешно“ се изедначуваат со медиумските претстави. Нискобуџетните сапуници стануваат суштинско разменување на мислите и „стабилна“ комуникација за верните гледачи. Постојат дури и цели фестивали на гастрономијата ${ }^{* *}$ кои го развиваат „пријателството“ меѓу младите луѓе, кое трае (едвај) додека трае фестивалот...

Оваа, гореанализирана естетика, се пронаоѓа во Санийарна енигма, а во делот „Санитарност како идентитетна категорија“ Котеска ваквиот вишок кој лесно конвертира во различен вишок (телесен, трендовски вишок - храна/болка/страдање) - го

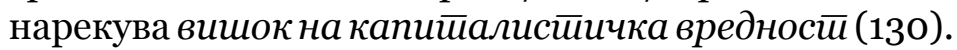
Имајќи го сето ова на ум, Јасна Котеска, дава на крај луциден коментар дека пораката за борба испишана на сапунот во „Боречки клуб“, кажува дека нешто не е во ред со самата идеја за криење, пред сѐ, криењето на она што се перцепира како валкано (125).

Постои ли при санитаризацијата воајеристичко задоволство?

\section{3. Економија на загубата. Валкан поглед}

Гардијан во еден свој број пишува за Трејси Емин (Tracey Emin), уметница, која во своите уметнички дела има специфичен дискурс, имено, трансгресивен воајеризам - свртеност кон самата себе. Што прави Трејси Емин во своите дела? Укажува на загубата.

** „Уметност и храна”, Фестивал АКТО, 2007, Скопје, Македонија qëndrueshëm” për shikuesit besnikë. Ekzistojnë madje edhe festivale të tëra të gastronomisë** të cilat e zhvillojnë "miqësinë" midis të rinjve, e cila zgjat (mezi) deri sa zgjat festivali...

Kjo estetikë, e analizuar lartë, gjendet në Enigmën sanitare, ndërsa në pjesën "Sanitarsia si kategori identiteti" Koteska tepricën e këtillë i cili konvertohet lehtë në në tepricë të ndryshme ( tepricë trupore, tepricë trendi - ushqim/dhembje/vuajtje) e quan tepricë të vlerës kapitaliste (130). Duke e pasur ndërmend tërë këtë, Jasna Koteska, e jep në fund një koment lucid se porosia për luftë e shkruar në sapunin në "Klubin e mundjes”, tregon se diçka nuk është në rregull me vetë idenë e fshehjes, para së gjithash fshehjes së asaj që perceptohet si e ndyrë (125).

A ekziston vallë sanitarizim i kënaqësisë vuajeriste?

\section{Ekonomia e humbjes. Pikëpamja e ndyrë}

Gardiani në një numër të vetin shkruan për Trejsi Eminin (Tracey Emin), artiste, e cila në veprat e saj artistike ka diskurs specifik, pra, vuajerizëm transgresiv - ktherje drejt vetvetes. Çka bën Trejsi Emin në veprat e veta? U bën me dije njerëzve për humbjen. Pra,, në një video të

** „Уметност и храна”, Фестивал АКТО, 2007, Скопје, Македонија 
Имено, на едно видео што го прикажува, таа постојано упорно ги прераскажува приказните за нејзиното израстување во сексуално - активно и злоставувано девојче во Маргејт (Guardian, November 1, 2003). Во делот со наслов „Сите со коишто сум спиела 19631995 (Everybody I’ve Ever Slept With 1963-1995)), на внатрешната страна од еден шатор, грижливо ги опишува сите оние со коишто спиела - љубовници, пријатели, семејството, па дури и абортираниот фетус. На публиката ѝ е фрлено во очи едно искуство на себеоткривање, изнесена интима низ видеоавтобиографија. Се поставува прашање, во која мера зборовите можат да ја покријат празнината која се чувствува? Во која мера тие се економија за загубата? Во која мера присилувањето да се зборува е обид за враќање на чистото, чистење на совеста низ прераскажување, низ упорна редундантност, со повторување на истата ситуација.

Во делот „Спреј (една можна феноменологија на пропаднатиот допир)“, Јасна Котеска од феноменологијата на зборување се префрла на феноменологијата на допирот. Во мигот кога валканиот, материјален допир, во една реклама, се заменува со погледот (како нематеријална инстанца). Рекламата за којашто зборува Јасна Котеска прикажува средство за сончање од козметичката куќа Лореал и оди вака: препаратот се нанесува со спреј и додека девојката се прска со спрејот, момчето стои оддалечено од неа и ја набљудува. Крајот на рекламата е заокружен со заводливи погледи меѓу двајцата. Котеска поентира дека исчекорот во оваа рекламна порака е дискурзивнойо помесшиввње во третманот на допирот - од еротски - кон допир со поглед. Таа вели:

„Производот беше изговор за да се допре. Не заштита од сонцето, туку покривање на телото што се допира од cilin ajo e shfaq, ajo vazhdimisht me ngulm i tregon me ngulm tregimet për rritjen e saj në një vashë seksualisht - aktive dhe të keqtrajtuar në Margejt (Guardian, November 1, 2003). Në atë pjesë me titull - "Të gjithë ata me të cilët kam fjetur 1963-1995 (Everybody I've Ever Slept With 1963-1995)) në anën e brendshme të një shatorreje me kujdes i përshkruan të gjithë ata me ata me të cilët ka fjetur - dashnorë. Miq, familje, madje edhe fetusi i abortuar. Publikut i është hedhur para sysh një përvojë e vetëzbulimit, njëfarë intime përmes viodeautobiografisë. Shtrohet pyetja, në çfarë mase fjalët mund ta mbulojnë zbrazëtinë e cila ndjehet? Në çfarë mase ato janë ekonomi për humbjen? Në çfarë mase detyrimi që të flasë është orvatje për kthimin e të pastrës, pastrim it të ndërgjegjes përmes përshkrimit tregues, përmes redudantësisë me përsëritjen e situatës së njëjtë.

Në pesën "Sprej (një fenomenologji e mundshme e kontaktit të shkatërruar fare)" - Jasna Koteska nga fenomenologjia e të folurit hidhet në fenomenologjinë e kontaktit. Në çastin kur kontakti i ndyrë, material, në një reklamë, zëvendësohet me shikimin (si instancë jomateriale). Reklama për të cilën flet Jasna Koteska, tregon për një mjet për rrezitje nga shtëpia kozmetike Loreal dhe shkon kështu: preparati qitet me prej dhe derisa vajza stërpiket me prej, djali qëndron larg saj dhe e vështron. Fundi i reklamës rrumbullakohet me shikime ngasëse midis të dyve. Kotesha poenton se hapi i kësaj porosie të reklamës është zhvendosja diskurzive në trajtimin e kontaktit - nga ai erotik kah kontakti me shikim. Ajo thotë:

"Prodhimi ishte një arsyetim që të ndodhë kontakti. Jo mbrojtje nga dielli, por mbulim i trupit që preket nga shiki- 
пуританскиот поглед. Заштита од осудувачкиот колектив, поради чиј поглед двете тела не мора да треперат во срам заради јавноста на допирот, бидејќи тие имаат изговор. Веќе не допира телото - туку допира погледот. Не допира она што се поти, што мириса, што расте, што се деформира, што се распаѓа. Допира она што никогаш не може вистински да допре, чија суштина е токму идеалноста на отсутносто. Сеприсутниот поглед е фундаментално отсутен“ (160).

Вознемируваат констатациите на Јасна Котеска дека се брише допирот, дека нема ништо нечисто во двете тела кои се допираат, а нечистотијата отпаѓa само на погледот на третиот кој не може да ја издржи глетката на туѓата материјалност отворена пред третото тело. (Поради завист?) Парадоксалноста се согледува во тоа што, додека погледот го третираме речиси како идеална категорија, исчистена од секаков талог на валканоста (во погледот нема ништо нечисто), во истиот момент констатираме дека погледот е суштински валкан, во проширената констатација дека „сега не си играат двата погледа во чинот на јавното допирање, туку сега си играат двата погледа во перверзната мрежа на сеопштото гледање на сите кон сите“ (161). Еротските погледи за коишто зборува Јасна Котеска се мртви допири. Има една исклучително точна разврска кај Котеска во однос на мимикријата на погледот. Имено, погледот дејствува интерсоцијално кога е во прашање допирот. Тој се обидува да го излаже субектот, да му го преведе осетот, но кога тој нема да успее - вели Котеска - тој ја шири измамата преку феноменот на социјалното гледање, бидејќи погледот од сите сетила е најсоцијален.

Ваквата мала студија за погледот од Котеска, отвора ново големо видување за него. Имено, Јасна Котеска забележува дека во современиот денешен свет на комуникација, се дава простор на означителите mi puritan. Mbrojtja nga kolektivi që dënon, para shikimit të së cilit dy trupat nuk është e thënë që të dridhen në turp për shkak të botnisë së kontaktit, për shkak se ata kanë arsyetim. Tashmë nuk prek trupi, por prek shikimi. Nuk prek ajo që kërkohet, që shpërndan erën e mirë, që rritet, që deformohet, që zbërthehet. Prek ajo që me të vërtetë asnjëherë nuk mund të prekë me të vërtetë, thelbi i së cilës është pikërisht idealsia e papranisë. Shikimi i gjithpranishëm është fundamentalisht i papranishëm"(160).

Të shqetësojnë konstatimet e Jasna Koteskës se shlyhet prekja, se nuk ka asgjë të të papastër në dy trupat të cilët preken, kurse papastërtia bie vetëm në shikimin e të tretit i cili nuk mund ta përballojë pamëninë e materialsisë së huaj të hapur para trupit të tretë. (Për shkak të zilisë?) Paradoksaliteti shihet në faktin se derisa shikimin e trajtojmë thuajse si kategori ideale, të pastruar nga çdo fundërrinë të ndyrësia (në shikim nuk ka asgjë të papastër_ _ në po atë moment konstatojmë se shikimi është në thelb i ndyrë, në konstatimin e zgjeruar se "tash nuk luajnë të dy shikimet në rrjetën perverse të shikimit gjithëpërfshirës të të gjithëve ndaj të gjithëve" (161). Shikimet erotike për të cilat flet Jasna Koteska janë prekje të vdekura. Është një zgjidhje jashtëzakonisht e saktë te Koteska në raport me mimikrinë e shikimit. Ai orvatet ta mashtrojë subjektin, t’ia përkthejë ndijën, por kur ai nuk do të ketë sukses - thotë Koteska - ai e zgjeron mashtrimin përmes fenomenit të të shikuarit social, me që shikimi nga të gjitha shqisat është më social.

Studimi i këtillë i vogël për shikimin nga Koteska e hap një pamje të re të madhe për të. Pra, Jasna Koteska vë re se në botën e sotme bashkëkohore të të komunikimit, jepet hapësirë shënuesve në vend të referentëve, ndërsa 
наместо на референтите, а погледот се издига над другите сетила. Технологијата на погледот го преведува материјалниот осет во нематеријален видлив осет, а сите други сетила ги первертира - во поглед. И ако се мислеше дека погледот е најсанитарен од сите сетила и дека во него не може да има нешто што е валкано, Котеска го докажува обратното - дека погледот секогаш има друга намера, односно, прво гледа валкано. Ваквото видување за погледот е значајно и во однос на одново дизајнирање на гледнийе йочки во наратологијата и визуелната култура, на нестабилноста на сезнаечкиот раскажувач - кој сѐ знае и сѐ гледа во културата. Со оваа студија Котеска покажува дека дискурсот за чистото и нечистото има сериозни врски со „легитимирањето“ на погледот, на неговата позиција и моќ да цензурира или да одобрува, да принудува или да дијалогизира. А во тој легитимитет учествува и цела индустрија на репрезентација.

Се поставува прашањето - од каде тој порив хистерично да се создава културна и медиумска потреба од козметика и привлечни санитарни производи? Во право е Котеска кога заклучува дека ваквата произведувачка индустрија има јаки врски со создавањето на „хигиенска“ империја која мора прво да создаде козметичка индустрија која ќе предводи на пазарот, чиишто производи ќе бидат основа за идно санкционирање на валканиците од другата (туѓата) цивилизација, со цел да создадат „легитимитет“ како што вели Котеска - да го гледаат валканото надвор од својот двор, земја, држава - „во 'вториот' и 'третиот' свет, во 'четвртиот' свет, на улиците на нашите поранешни колонии, во валканите предградија на 'сомнителните' континенти...“) (173).

Санийарна енигма е освежувачка теориска студија во македонската книжевна наука, па и пошироко, shikimi ngrihet mbi ndijat tjera. Teknologjia e shikimit e përkthen ndijën materiale në ndijë jomateriale - të dukshme, kurse të gjitha ndijat tjera i perverton në shikim. Dhe, nëse mendohej se shikimi është më sanitar nga të gjitha ndijat dhe se në të nuk mundet të ketë diçka që është e ndyrë, Koteska e dëshmon të kundërtën - se shikimi gjithmonë ka qëllim tjetër, përkatësisht, së pari shikon ndyrësisht. Pikëpamja e këtillë për shikimin është e rëndësishme edhe në raport me disejnimin e sërishëm të pikave të shikimit në narratologjinë dhe kulturën vizuale, me jostabilitetin e tregimtarit të gjithdishëm i cili di çdo gjë dhe sheh çdo gjë në kulturë. Me këtë studim Koteska tregon se diskursi për të pastrën dhe të papastrën ka lidhje serioze me "legjitimimin" e shikimit, të pozitës dhe fuqisë së tij - të censurojë ose të lejojë, të detyrojë ose të dialogizojë. Kurse në atë legjitimitet merr pjesë edhe e tërë industria e reprezentimit.

Shtrohet pyetja - prej nga ajo nevojë që historikisht të krijohet nevoja kulturore e mediave për kozmetikë dhe prodhime tërheqëse sanitare? Ka të drejtë Koteska kur vjen në përfundim se industria e tillë prodhuese ka lidhje të forta me krijimin e perandorisë "higjienike" e cila është e detyruar së pari të krijojë një industri kozmetike e cila do të prijë në treg, prodhimi i së cilës do të jenë bazë për sanksionimin e ardhshëm të ndyrësive nga civilizimi tjetër (i huaj), me qëllim të krijojnë "legjitimitet" - siç thotë Koteska - ta shohin të ndyrën jashtë oborrit, vendit, shtetit të vet - në botën "tjetër", dhe "të tretën”, në botë "e katërt", në rrugët e ish kolonive tona, në paralagjet e ndyra të kontinenteve "të dyshimta”...) (173).

Enigma sanitare është një studim teorik i freskët në shkencën letrare maqedonase, por edhe më gjerë, në 
во македонската наука за теорија на уметноста. Припаѓа на „мал“ јазик/книжевност/историја/култура каква што (во туѓи очи) е и македонската, но е одлично конкурентна студија со современите текови на анализи во овие години на овој век. Притоа, не смее да се заборави дека постои и само поради погледот на тие туѓи очи - на другиот, на третиот како логичка неопходност од постоење - трет член во друштвото. Бидејќи, како што одлично забележува Јасна Котеска, зад идејата на канонот за санитарност, всушност стои стравот од несувереноста на свеста, па дури и на големите империјалистички држави, што е страв од губење на континуираната историја, која во свеста секогаш си бара своја гаранција. Оваа книга е сериозно, драматично ревидирање на таквата свест.

Библиографија:

Academy Royal of Arts. 1997. Sensation: Young British Artist from the Saatchi Collection. Royal Academy of Arts: London.

Deleuze, Gilles and Guattari, Felix. 1992. A Thousand Plateaus, Capitalism and Shizophrenia. London: The Athlone Press.

Huyssen, A. 1986. After the Great Divide: Modernism, Mass Culture and Postmodernism. London: Macmillan.

Котеска, Јасна. 2007. „Идеалното чисто го има само во ништото“ - интервју Ивана Тасев со Јасна Котеска, Теа Модерна, 25 април. 2006. Санитарна енигма. Скопје: Темплум.

Kristeva, Julia. 1982. Powers of Horror, An Essay on Abjection. New York: Columbia University Press.

Lacan, Jacques. 1986. Četiri temeljna pojma psihoanalize. XI Seminar. Zagreb: Naprijed. shkencën maqedonase për teorinë e artit. I takon një gjuhe/letërsie/historie/kulture "të vogël” siç është (në sytë e huaj) jona maqedonase, por është një studim i shkëlqyeshëm konkurrent me ecuritë bashkëkohore të analizave të këtyre viteve të këtij shekulli. Me këtë rast, nuk guxojmë të harrojmë se ekziston dhe vetëm për shkak të shikimit të atyre syve të huaj - të tjetrit, të tretit - si domosdoshmëri logjike e ekzistencës - anëtar i tretë në shoqëri. Meqë, siç vë në dukje në mënyrë të shkëlqyeshme Jasna Koteska, prapa idesë së kanonit të sanitarësisë, në të vërtetë qëndron frika nga josovraniteti i vetëdijes, e madje edhe i shteteve të mëdha imperialiste që është frikë nga humbja e historisë së vijueshme, e cila në vetëdije kërkon gjithmonë garancinë e vet. Ky libër është një revidim serioz, dramatik i një vetëdijeje të tillë.

Përkthim: Xhabir Ahmeti

Referenca:

Academy Royal of Arts. 1997. Sensation: Young British Artist from the Saatchi Collection. Royal Academy of Arts: London.

Deleuze, Gilles and Guattari, Felix. 1992. A Thousand Plateaus, Capitalism and Shizophrenia. London: The Athlone Press.

Huyssen, A. 1986. After the Great Divide: Modernism, Mass Culture and Postmodernism. London: Macmillan.

Котеска, Јасна. 2007. „Идеалното чисто го има само во ништото“ - интервју Ивана Тасев со Јасна Котеска, Теа Модерна, 25 април.

. 2006. Санитарна енигма. Скопје: Темплум.

Kristeva, Julia. 1982. Powers of Horror, An Essay on Abjection. New York: Columbia University Press.

Lacan, Jacques. 1986. Četiri temeljna pojma psihoanalize. XI Seminar. Zagreb: Naprijed. 
Riviere, J. 1986. "Womanliness as Masquerade." In Formations of Fantasy. Edited by V. Burgin. London: Methuen.

Sturken, Marita and Lisa Cartwright. 2000. Practices of Looking. An Introduction to Visual Culture. Oxford University Press.
Riviere, J. 1986. "Womanliness as Masquerade." In Formations of Fantasy. Edited by V. Burgin. London: Methuen.

Sturken, Marita and Lisa Cartwright. 2000. Practices of Looking. An Introduction to Visual Culture. Oxford University Press. 